THE INTERNATIONAL

REVIEW OF RESEARCH IN

OPEN AND DISTANCE LEARNING

\title{
Motivation Levels among Traditional and Open Learning Undergraduate Students in India
}
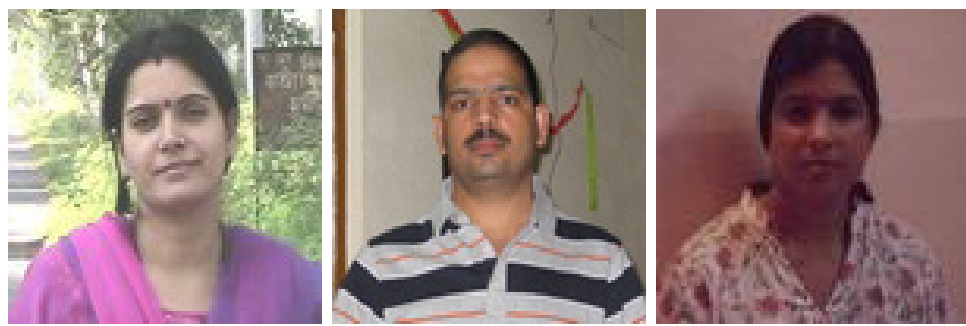

Shashi Singh and Ajay Singh

Meerut Institute of Engineering \& Technology, India

Kiran Singh

University of Allahabad, India

\section{Abstract}

Motivation plays a crucial role in learning. Motivation energizes the behavior of the individual. It also directs the behavior towards specific goals. It helps students acquire knowledge, develop social qualities, increase initiation, persist in activities, improve performance, and develop a sense of discipline. This paper aims to compare the levels of motivation between students in the open education system (OES) and in the traditional education system (TES) in India. The study further investigates the motivation levels of male and female students in the two systems. An Academic Motivation Scale (AMS) was prepared and administered on the students of TES $(n=200)$ and OES $(n=151)$. Results show that there exist significant differences in the level of motivation between the students of TES and OES. The study concludes that it is the presence or absence of extrinsic motivation which is predominantly responsible for this difference.

Keywords: Traditional education system; open education system; academic motivation; survey 


\section{Introduction}

Motivation is typically defined as the force that accounts for the arousal, selection, direction, and continuation of behavior. Motivation means the desire and willingness to do something. It is a drive that compels an individual to act towards the attainment of some goal. As defined by Daft (1977, p. 526), "Motivation refers to the forces either within or external to a person that arouse enthusiasm and persistence to pursue a certain course of action." Motivation plays a crucial role in learning. It not only sets in motion the activity resulting in learning, but also sustains and directs it. It is "the central factor in the effective management of the process of learning" (Kelley, 2002, as cited in Aggarwal, 2004). Academic motivation has been found to be positively associated with academic achievement, academic performance, and the "will to learn" (McCelland et al., 1953; Entwistle, 1968; Frymier et al., 1975). Various studies have found that classroom competition (Bolocofsky, 1980), family culture and environment (Tseng, 1998; Satyanandam, 1969; Hussain, 1977; Salunke, 1979; Nagalakshmi, 1982; Singh, 1984), personal aspiration factors (Yeung \& Yeung; 2001, Banerjee; 1974, Siddiqui; 1979), and study habits (Tiwari, 1982) positively motivate students to do better.

Open learning has afforded opportunities for education outside the realm of the conventional system by providing flexibility in pursuing courses and taking examinations (Gautam, 1990; Indradevi, 1985). Studies have further stated that the popularity and acceptance of open education systems is on the rise (Bhattacharya, 1991; Khan, 1991). Freedom from constraint may also be seen as a defining feature of distance learning, for example freedom of content, space, medium, access (Paulsen, 1993), and relationship development (Anderson, 2006, as cited in Hartnett et al., 2011). Other than flexibility, job-related goals (Wanieweicz, 1981) and improvement of social status (McIntosh, 1978) are the main motivation to join the open education system. It has also been revealed that the chances of students successfully completing their open education studies is generally linked to their personal concept (Gibson, 1996), capacity for self-management (Atman, 1988), and familiarity with technology (Schifter \& Monolescu, 2000). Notwithstanding the advantages that distance education offer, retention of students has been a major area of concern in open education. Dropout rates reported by open and distance learning (ODL) institutions are typically higher than those reported by conventional universities (Pierrakeas et al., 2004). Pierrakeas et al. (2004) further report the following:

In Europe, dropout rates in distance education programs typically range from 20 percent to 30 percent (Rumble, 1992) or even higher in Northern America (Schlosser \& Anderson, 1994). Asian countries have recorded rates as high as 50 percent (Shin \& Kim, 1999; Narasimharao, 1999). (p.1)

Various reasons such as family (related to childbirth, child rearing, marriage, pregnancy, travel problems, death of a family member), personal, or health reasons (Pierrakeas et al., 2004), distance to the study center, insufficient academic support from study centers, ab- 
sence of interaction with other students, and insufficient counseling sessions (Fozdar et al., 2006) have been found to contribute to higher dropouts in the open education system. Apart from these explicit factors, poor motivation has been identified as a decisive factor in contributing to the high dropout rates from online courses (Muilenburg \& Berge, 2005). Against this backdrop of poor retention rates, the diverse characteristics of distance learners and the importance of motivation in the learning process prompted our study. This study explores whether the level of motivation in OES students compared to TES students is low enough to raise apprehension among distance education administrators. Issues have been raised and explored regarding the motivation of students of TES and OES. Further, motivation has been explored from extrinsic and intrinsic points of view. While intrinsic motivation is important to influence the learning habits of students, particularly in OES (Shroff, Vogel, \& Coombes, 2008; Rovai, Ponton, Wighting, \& Baker, 2007; Wighting et al., 2008), this study also examines the importance of extrinsic motivation in the formation of the overall motivation level of students.

\section{Objectives of this Study}

Though it may not seem logical to compare the pupils of the two types of education systems, which differ so widely in their characteristics and functioning, the researchers have undertaken this study to explore the reasons, if any, for the differences in motivation levels. The study aims to discover the learning motivations of OES and TES students. The study compares academic motivation between the two education systems. It also incorporates a comparison between male and female students studying under the two systems. The various dimensions that have influence on the motivation level of students are discussed.

The objective of this study is also to apply the theories of motivation to explore the reasons for any significant differences in the motivation levels of the two types of pupil. This study will present suggestions which may be beneficial for policy makers. It will also raise questions which may be the subject matter of future research. To achieve the above stated objectives and after reviewing the related literature the following hypotheses have been framed and tested.

Hypothesis 1: There is no significant difference in the academic motivation of students studying in the two systems of education.

Hypothesis 2: There is no significant difference in the academic motivation of male and female students studying in the two systems of education.

Hypothesis 2 has further been subdivided into the following hypotheses.

Hypothesis 2(a): There is no significant difference in the academic motivation of the male and female students studying in the traditional education system.

Hypothesis 2(b): There is no significant difference in the academic motivation of the male and female students studying in the open education system. 
Hypothesis 2(c): There is no significant difference in the academic motivation of the male students studying in the traditional education system and in the open education system.

Hypothesis 2(d): There is no significant difference in the academic motivation of the female students studying in the traditional education system and in the open education system.

\section{Delimitations of this Study}

The present study has the following delimitations:

- It is confined to undergraduate students only.

- It is confined to two faculties, namely the arts and science faculties.

- The population under study is limited to the municipal limits of Allahabad Municipal Area (Uttar Pradesh, India).

- The sample size of the present study is limited to 351 students.

- The present study is limited in its design, method, measuring devices, and statistical techniques.

\section{Method}

The present study is closely connected with the normative survey method of research. The population for the present study has been defined as all B.A. and B.Sc. students (male and female) of session 2009-2010 studying in the degree colleges affiliated to Allahabad University and Allahabad study centre of U.P. Rajarshi Tandon Open University who have gone through the process of examination and evaluation of their respective educational system at least once.

The population for the traditional education system has been defined as the number of students studying in the degree colleges offering B.Sc. and B.A. courses in Allahabad city region; these degree colleges are affiliated to the University of Allahabad. Only second and third year undergraduate students have been considered as members of the population as they have gone through the examination and evaluation process of their education system. At the time of the study, a total population of 13,748 students from nine colleges was eligible to participate.

The population for the open education system has been defined as the number of students enrolled with Uttar Pradesh Rajarshi Tandon Open University, Allahabad, for the courses in the arts and science streams. Their study centers are based in Allahabad. This university conducts examinations each semester, which is why the population constitutes all the students studying in the first, second, and third years of their respective stream ( $n=305$ from 
five study centers). Those first year students considered to be part of the population have appeared and cleared their first-semester examination, thus fulfilling the criterion of "going through the examination and evaluation process."

\section{Sample Size}

In the present study a stratified random sampling method has been used as Miller (1977, p.52) pointed out that "the essential requirement of any sample is that it is as representative as possible of the population or the universe from which it has been drawn."

The proposed sample size was supposed to be 400 (200 TES and 200 OES) but due to the scarcity of science students enrolled under OES, the actual sample size is as given in Table 1.

Table 1

Actual Sample Design

\begin{tabular}{|l|l|c|c|c|}
\hline \multicolumn{2}{|l|}{ Undergraduate students } & $\begin{array}{c}\text { Traditional education } \\
\text { system }\end{array}$ & Open education system & Total \\
\hline \multirow{2}{*}{ Arts } & Male & 50 & 50 & 100 \\
\cline { 2 - 5 } & Female & 50 & 50 & 100 \\
\hline \multirow{2}{*}{ Science } & Male & 50 & 37 & 87 \\
\cline { 2 - 5 } & Female & 50 & 14 & 64 \\
\hline \multicolumn{2}{|l|}{ Total } & 200 & 151 & 351 \\
\hline
\end{tabular}

\section{Instruments}

The questionnaire used in the present study is primarily a self-developed tool named the Academic Motivation Scale (AMS). A few other standard questionnaires were studied to find their suitability for the present study. No published tool was found suitable by the authors in its exact original form as none catered to the needs of college going students of TES and OES. Development of this instrument has taken inputs from the one that was published and developed by Srivastava (1974) with the title Academic Motivation Inventory. This tool is adapted to Indian conditions and is meant to test the academic motivation of secondary school students. There are 58 items in the tool of which 29 items are positive and 29 negative. This instrument has three dimensions, namely academic aspiration (22 statements), study habits (20 statements) and attitude toward school (16 statements).

The questionnaire used in this study has taken help from the standardized tool developed by Srivastava. The present tool has retained the three dimensions of the Academic Motivation Inventory and added another dimension, social-family-economic (environment). Since college students, whether under TES or OES, have more exposure and interactions with different elements of society and environment, they are more vulnerable to developing positive or negative academic motivation levels as per their environment. Hence, the 
dimensions used in the questionnaire are as follows:

- personal aspiration,

- study habits,

- $\quad$ social-family-economic (environment) factors, and

- attitude towards college/ study centre.

A five-point rating scale was prepared by the researcher with the following alternatives: strongly agree, agree, undecided, disagree, and strongly disagree. Having identified the items, the preliminary tool was tested on 40 students consisting of 20 students from TES and 20 students from OES belonging to the science stream or the arts stream. Emphasis was laid upon the inclusion of male, female, rural, and urban students in the proper ratio. The tool was administered to examine the gross language mistakes and identify the defects, if any. After making the necessary corrections AMS was administered on 150 students.

\section{Final Form of Questionnaire}

Nine items due to $t$-value and five items due to item validity and item difficulty were rejected. Therefore 46 items remained. These 46 items or statements can be deemed as completely fit and appropriate for further use. In the final form of the AMS, there were 15 items for measuring the first dimension (i.e., personal aspiration), 15 items for the second dimension (i.e., study habits), 8 items for the third dimension (i.e., socioeconomic factors), and 8 items for the fourth dimension (i.e., attitude towards college/study centers). The final scale (AMS) contained 22 favorable and 24 unfavorable statements. The tool was standardized by judging reliability using the split half method (the correlation coefficient was found to be 0.87 and when corrected it was 0.93) and test-reset method (moment product correlation coefficient was 0.97) and incorporating suggestions from students, educationists, psychologists, and specialists working in the field of education (traditional as well as open).

\section{Brief Description of Dimensions of AMS}

The following four dimensions have been taken in designing AMS to analyze the academic motivation of students, keeping in mind the characteristics of the research population.

\section{Personal aspiration.}

This is an intrinsic motivation that energizes an individual to perform certain tasks. It is the main driving force that guides a student through the process of learning. A stronger feeling of self-determination and competence will have a positive impact on the development of a student's academic motivation, whereas the opposite will have a negative impact (Deci \& Ryan, 1991, cited in Karsenti, 1999). 


\section{Study habits.}

Habit is customary behavior or something that a person does naturally and enjoys doing. Analysis of an individual's habit pattern reflects the level of commitment and determination regarding certain tasks. This domain is a visible component of intrinsic motivation in the form of action and behavior compared to personal aspiration which is generally not visible. Hull's drive theory (1943) cited in Beck (2005, p. 149) says that drive multiplied by habit produces the excitatory potential for a response: Excitatory potential $=$ habit $\mathrm{X}$ drive.

Thus, intrinsic motivation when combined with extrinsic motivation may result in the development of good habits (actions) to fulfill the drives (internal) by maximizing potential (efforts). So analysis of study habit patterns is helpful in determining the level of motivation of TES and OES students.

\section{Social-family-economic (environment) factors.}

Personality and individual differences affect the motivation level and behavior of a person. The personality traits of an individual are often influenced and governed by environmental factors. The environment provides various cues and important extrinsic motivation factors to initiate action and energize intrinsic motivation. Hartman (2001) cited in Kawachi (2006) says that cognition, affect, metacognition, and environment are four interrelated dimensions associated with learning.

\section{Attitude towards college/ study centre.}

Attitude is a learned tendency or predisposition to respond in a consistently favorable or unfavorable manner to some concept, situation, or object. Beck (2005) says that cognitive inconsistency occurs when an event is perceived to be different from an expectation. Such inconsistencies may be arousing and may induce attitude change. In the present study, attitude towards college/study center refers to the opinion or general feeling the students have towards their college/study centre depending upon the consistency or inconsistency of events with their expectations.

\section{Brief Description of Some of the AMS Statements}

A few AMS items are presented below in the form of a continuum (having Likert-scaletype statements), which we used in the questionnaire to assess the motivation level among students.

Understanding the concepts is more important even if it jeopardizes the chances of completion of the subject within stipulated time.

Marks/percentage plays important role in one's academic success. $\longleftrightarrow$ Completing the syllabus within stipulated time has greater importance than to understand the concept.

More than marks/percentage, it is only the degree that counts. 
I am always curious to collect information which may result in obtaining good marks.

Always anxious to submit assignments on time.

I sincerely try to keep aside some time for my studies on regular basis.

I feel frustrated when I am not able to spare some time for studies.

I try to make an extra effort to receive feedback and suggestions related to study matters. $\longleftrightarrow$ I am happy and satisfied if I could get some time to study which may be helpful in passing the exam

$\longleftrightarrow \quad$ My professional and family commitments hardly allow me to complete my assignments in time.

$\longleftrightarrow$ I seldom get time to focus on my studies.

I know to fulfill my responsibilities and interests are my utmost duties. I try to study when I get spare time or when it becomes the necessity.

$\longleftrightarrow$ I hardly found any competent person around me who can guide me in my studies.

Figure 1. Some of the statements used in the Academic Motivation Scale.

\section{Statistical Technique Used}

Statements of the AMS were coded and arranged. Then, the $t$-test (Garrett, 1981, pp. 243245) statistical technique was used to investigate the different hypotheses.

\section{Data Analysis}

\section{Hypothesis 1}

To test this hypothesis, the Academic Motivation Scale was administered to 200 TES students and 151 OES students. The data is shown in Table 2.

Table 2

Comparison of Academic Motivation of Students Studying in TES and OES

\begin{tabular}{|l|c|c|c|c|}
\hline Education system & Mean & Standard Deviation & $\begin{array}{c}\text { Degree of } \\
\text { Freedom }\end{array}$ & $t$-value \\
\cline { 1 - 3 } Traditional $(n=200)$ & 153.30 & 24.91 & 349 & 6.07 \\
\cline { 1 - 3 }$(n=151)$ & 138.13 & 21.79 & & \\
\hline
\end{tabular}

t critical two tail: 1.97 (at 0.05 significant level)

The value of $t$ was found to be 6.07 which is significant. Thus the hypothesis is rejected and it can be said that there is significant difference in the academic motivation of students studying in the two systems of education. 
Figure 2 is plotted for the comparison of mean values of the academic motivation of students studying under the two systems.

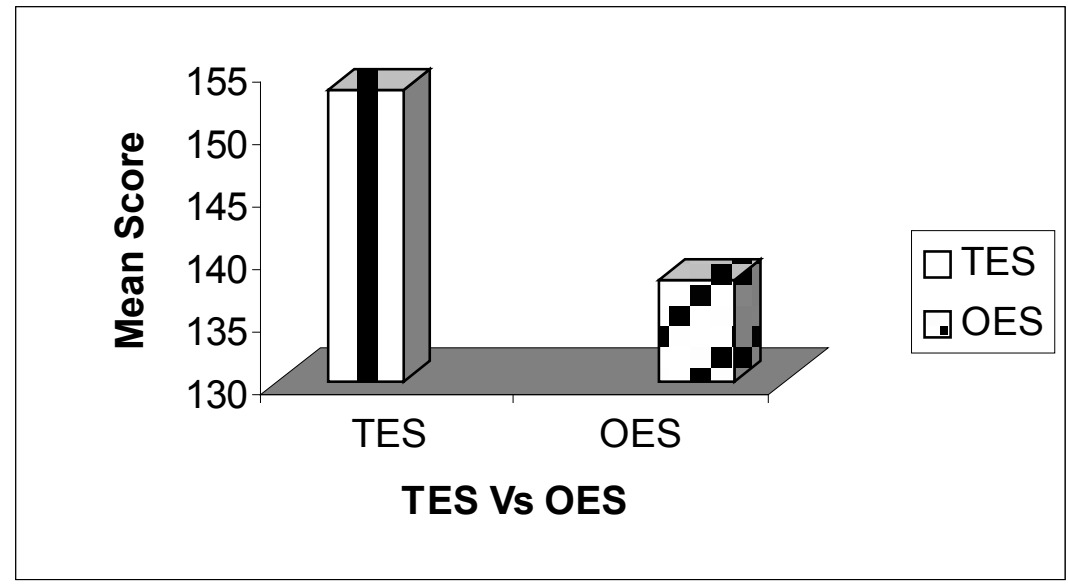

Figure 2. Comparison of mean values (academic motivation) of students studying under TES and OES.

The results show that TES students have higher mean scores compared to the mean scores of OES students. The greater difference in their means suggests that TES students are motivated more when compared to OES students. Dimension-wise analysis of the data is shown in Table 3 and in Figure 3.

Table 3

Comparison of Academic Motivation of Students Studying in TES and OES Dimensionwise

\begin{tabular}{|c|c|c|c|c|c|c|c|}
\hline \multirow{3}{*}{ S. No. } & \multirow{3}{*}{ Dimension } & \multicolumn{4}{|c|}{ Total student } & \multirow{3}{*}{$\begin{array}{l}t- \\
\text { value }\end{array}$} & \multirow{3}{*}{$\begin{array}{l}\text { Significant/ } \\
\text { insignificant }\end{array}$} \\
\hline & & \multicolumn{2}{|c|}{$\begin{array}{l}\text { Traditional } \\
\text { education } \\
\text { system } \\
(n=200)\end{array}$} & \multicolumn{2}{|c|}{$\begin{array}{l}\text { Open educa- } \\
\text { tion system } \\
(n=151)\end{array}$} & & \\
\hline & & $M$ & $S D$ & $M$ & $S D$ & & \\
\hline 1 & Personal aspiration & 51.03 & 7.88 & 46.68 & 8.70 & 4.83 & Significant \\
\hline 2 & Study habits & $49 \cdot 32$ & 8.33 & 43.83 & 7.62 & 6.42 & Significant \\
\hline 3 & $\begin{array}{l}\text { Social-family-economic envi- } \\
\text { ronment }\end{array}$ & 25.87 & $5 \cdot 42$ & 22.51 & 3.96 & 6.70 & Significant \\
\hline 4 & $\begin{array}{l}\text { Attitude towards college/ } \\
\text { study centre }\end{array}$ & 27.09 & 5.11 & 25.11 & $3 \cdot 31$ & $4 \cdot 39$ & Significant \\
\hline
\end{tabular}




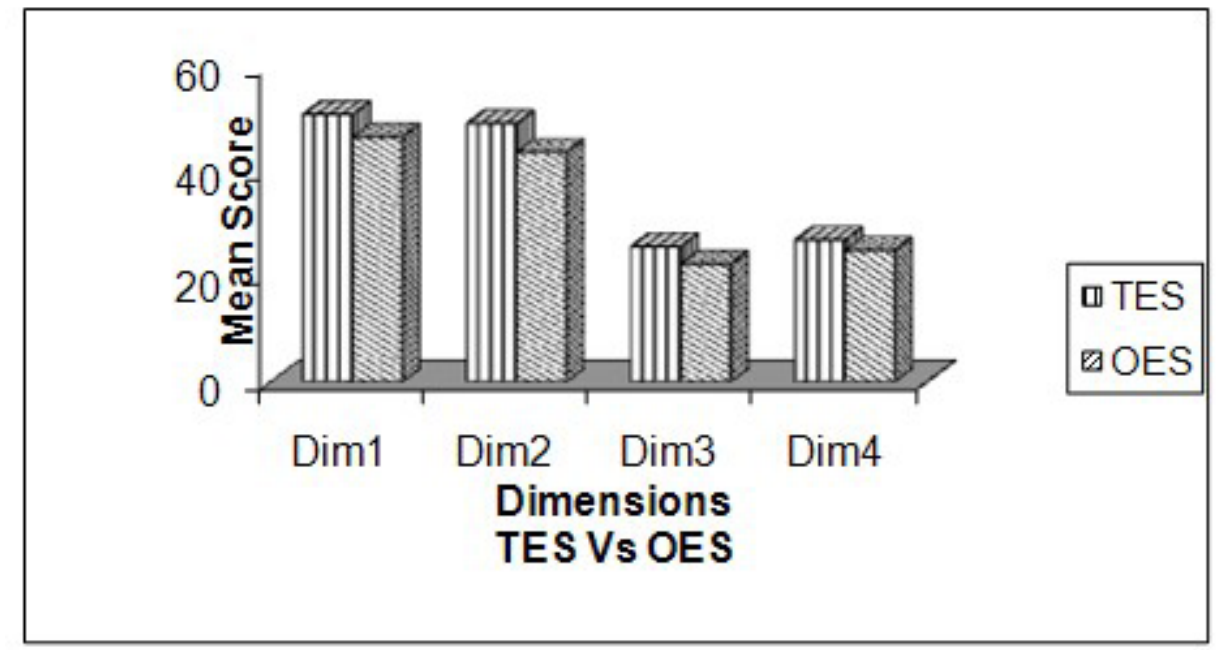

Figure 3. Dimension-wise comparison of mean values for academic motivation of TES and OES students.

On all dimensions, there is significant difference in academic motivation between students of the two education systems (Table 3). The amount of significant difference is highest for the social-family-economic dimension. Difference in study habits is also very prominent between the two types of education systems. TES students score high on personal aspiration. The performance of TES students is monitored more closely by their parents and society than the performance of OES students, which may be why they are influenced more by the social-family-economic environmental conditions. Such environmental scrutiny results in the appearance of extrinsic motivation as an important factor in the TES students. Regular classroom teaching and student-teacher interactions are common features of TES. These factors result in the development of better study habits and attitudes toward their college. On the other hand, analysis of questionnaire statements reveals that the OES students are studying to upgrade their existing qualifications or to get essential degrees required for their jobs. Merely passing the examination is of prime importance to them. The social factor does not have much influence on OES students, and intrinsic motivation is the dominant factor in these students' will to learn.

\section{Hypothesis 2(a) and 2(b)}

The scores of the Academic Motivation Scale were segregated for male ( $n T E S=100 ; n O E S$ $=87)$ and female $(n T E S=100 ; n O E S=64)$ students and $t$-test was calculated with the following results (Table 4). 
Table 4

T-Test Analysis of Academic Motivation of Male and Female Students Studying in TES and OES

\begin{tabular}{|l|c|c|c|c|}
\hline Traditional education system & Mean & $\begin{array}{c}\text { Standard } \\
\text { Deviation }\end{array}$ & $\begin{array}{c}\text { Degree of } \\
\text { Freedom }\end{array}$ & $t$-value \\
\cline { 1 - 3 } Male $(n=100)$ & 152.30 & 25.80 & 100 & -0.57 \\
\cline { 1 - 3 } Female $(n=100)$ & 154.30 & 24.07 & Insignificant \\
\cline { 1 - 3 } Open education system & Mean & $\begin{array}{c}\text { Standard } \\
\text { Deviation }\end{array}$ & $\begin{array}{c}\text { Degree of } \\
\text { Freedom }\end{array}$ & $t$-value \\
\cline { 1 - 3 } Male $(n=87)$ & 136.92 & 23.41 & 149 & -0.81 \\
\cline { 1 - 3 } Female $(n=64)$ & 139.77 & 19.43 & & Insignificant \\
\hline
\end{tabular}

t Critical two-tail: 1.97 (at 0.05 significant levels)

The value of $t$ was found to be -0.57 and -0.81, which is insignificant. Thus hypothesis 2(a) and 2(b) are accepted and it can be said that there is no significant difference in the academic motivation of male and female students, whether studying in TES or OES. It is also observed that, although there is no significant difference, female students have slightly better motivation compared to their male counterparts in both systems.

\section{Hypothesis 2(c) and 2(d)}

To test hypothesis 2(c) and 2(d), the AMS scores were consolidated for male and female students. The details of the data are as shown in Table 5 .

Table 5

T-Test Analysis for the Comparison of Academic Motivation of Male Students and Female Students Studying in TES and OES

\begin{tabular}{|c|c|c|c|c|}
\hline Male students & Mean & Standard Deviation & $\begin{array}{l}\text { Degree of } \\
\text { Freedom }\end{array}$ & $t$-value \\
\hline Traditional $(n=100)$ & 153.30 & 25.80 & \multirow[t]{2}{*}{185} & \multirow{2}{*}{$\begin{array}{c}\quad 4.87 \\
\text { Significant }\end{array}$} \\
\hline Open $(n=87)$ & 136.92 & 23.41 & & \\
\hline Female students & Mean & Standard Deviation & $\begin{array}{l}\text { Degree of } \\
\text { Freedom }\end{array}$ & $t$-value \\
\hline Traditional $(n=100)$ & $154 \cdot 30$ & 24.06 & \multirow[b]{2}{*}{162} & \multirow{2}{*}{$\begin{array}{c}\quad 4.25 \\
\text { Significant }\end{array}$} \\
\hline Open $(n=64)$ & 139.77 & 19.43 & & \\
\hline
\end{tabular}

t Critical two-tail: 1.97(at 0.05 significant levels) 
The value of $t$ was found to be 4.87 for male students and 4.25 for female students, which is significant. Thus hypothesis 2(c) and 2(d) are rejected and it can be deduced that there is significant difference in the academic motivation of TES and OES male students and TES and OES female students.

Table 6

T-Test Analysis for the Comparison of Academic Motivation of Male Students and Female Students Studying in TES and OES: Dimension-Wise

\begin{tabular}{|c|c|c|c|c|c|c|c|}
\hline \multirow{3}{*}{ S.No. } & \multirow{3}{*}{ Dimension } & \multicolumn{4}{|c|}{ Male students } & \multirow{3}{*}{ t-value } & \multirow{3}{*}{$\begin{array}{l}\text { Significant/ } \\
\text { insignificant }\end{array}$} \\
\hline & & \multicolumn{2}{|c|}{$\begin{array}{l}\text { Traditional ed- } \\
\text { ucation system } \\
(n=100)\end{array}$} & \multicolumn{2}{|c|}{$\begin{array}{l}\text { Open educa- } \\
\text { tion system } \\
(n=87)\end{array}$} & & \\
\hline & & $M$ & $S D$ & $M$ & $S D$ & & \\
\hline 1 & Personal aspiration & 50.77 & 8.38 & 46.05 & 9.29 & 3.63 & Significant \\
\hline 2 & Study habits & 49.22 & 8.36 & 43.47 & 7.95 & 4.81 & Significant \\
\hline \multirow[t]{2}{*}{3} & $\begin{array}{l}\text { Social-family-economic } \\
\text { environment }\end{array}$ & 25.64 & $5 \cdot 36$ & 22.31 & $4 \cdot 37$ & 4.67 & Significant \\
\hline & $\begin{array}{l}\text { Attitude towards college/ } \\
\text { study centre }\end{array}$ & 26.67 & 5.28 & 25.09 & $3 \cdot 52$ & 2.43 & Significant \\
\hline & & \multicolumn{4}{|c|}{ Female students } & & \\
\hline \multirow[b]{2}{*}{ S.No. } & \multirow[b]{2}{*}{ Dimension } & \multicolumn{2}{|c|}{$\begin{array}{l}\text { Traditional ed- } \\
\text { ucation system } \\
(n=100)\end{array}$} & \multicolumn{2}{|c|}{$\begin{array}{l}\text { Open educa- } \\
\text { tion system }\end{array}$} & \multirow[t]{2}{*}{$t$-value } & \multirow{2}{*}{$\begin{array}{l}\text { Significant/ } \\
\text { insignificant }\end{array}$} \\
\hline & & $M$ & $S D$ & $M$ & $S D$ & & \\
\hline 1 & Personal aspiration & 51.29 & 7.37 & 47.55 & 7.81 & 3.06 & Significant \\
\hline 2 & Study habits & 49.42 & 8.34 & $44 \cdot 31$ & 7.17 & 4.17 & Significant \\
\hline \multirow[t]{2}{*}{3} & $\begin{array}{l}\text { Social-family-economic } \\
\text { environment }\end{array}$ & 26.09 & 5.10 & 22.78 & $3 \cdot 31$ & 4.80 & Significant \\
\hline & $\begin{array}{l}\text { Attitude towards college/ } \\
\text { study centre }\end{array}$ & 27.50 & $4 \cdot 91$ & 25.13 & 3.02 & 3.83 & Significant \\
\hline
\end{tabular}

df :185, t Critical two-tail: 1.97(At 0.05 significant levels) 


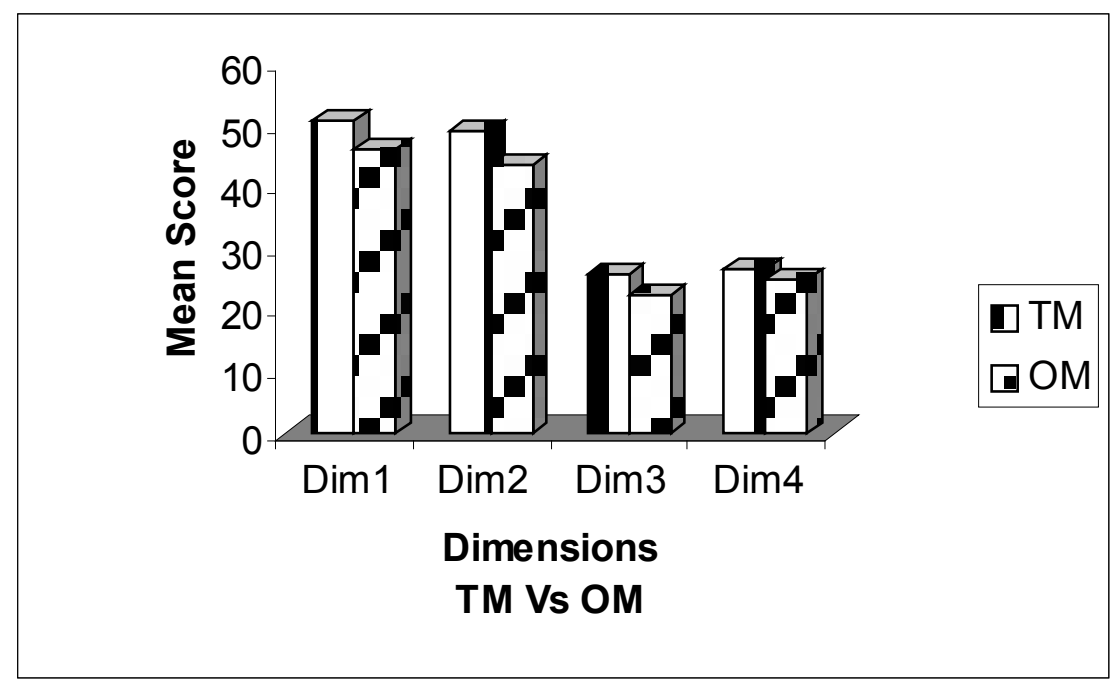

Figure 4. Dimension-wise comparison of mean values for academic motivation of TES and OES male students.

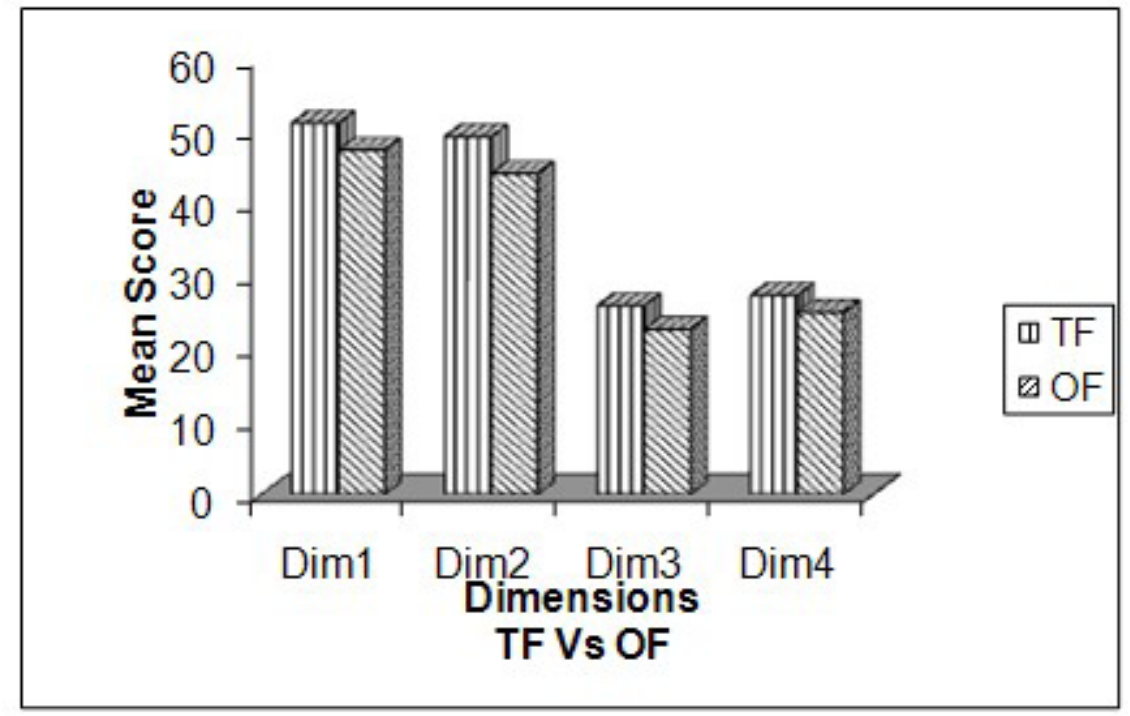

Figure 5. Dimension-wise comparison of mean values for academic motivation of TES and OES female students.

The examination of hypothesis 2(c) reveals that male students of the two education systems differ significantly in their motivation levels. Similarly examination of hypothesis 2(d) reveals that female students of the two education systems differ significantly in their motivation levels. Overall averages of the scores obtained by the male and female TES students are higher than those of the OES students. This means that the male and female students studying in TES are motivated more towards their studies when compared to male and female students studying in OES.

Dimension-wise analysis (Figure 4 \& Figure 5) suggests that TES students (male and female) have high mean values on all of the dimensions (in the order of study habits, personal aspiration, social-family-economic, and attitude towards college/study center), and there 
is significant difference between TES and OES students on each dimension. If we compare the AMS dimensions of male students (TES and OES) to female students (TES and OES), it is seen that the social-family-economic dimension difference is largest when female students of OES and TES are compared and the study habit dimension when male students are compared. Similarly it is seen that female students in general have a better attitude towards their colleges/study centers and personal aspiration. It is also visible from Table 6 that TES and OES male students show larger variability in mean responses.

The following conclusions can be drawn from the above discussion.

- There is no significant difference in the motivation level of the male and female students if compared within the same education system.

- Female students are slightly more motivated than the male students if compared within the same education system.

- There is a significant difference in the motivation level of the male students if compared between the two education systems.

- There is a significant difference in the motivation level of the female students if compared between the two education systems.

- Female students studying under TES have a greater positive attitude towards their colleges as compared to male students under TES.

- Female students of both systems have better study habits and they are more comfortable with their courses and curriculum than the male students.

- The influence of socioeconomic factors is greater on male and female students studying under TES than the students studying under OES.

\section{Descriptive Analysis of Questionnaire}

Analysis of the questionnaire revealed that 177 TES students out of 200 cited "fear of loss of image in family and society" as one of the major motivations to study many hours to clear the exam successfully. But no such fear was found among OES students; instead, these students wanted to successfully complete the course for their satisfaction and for future career advancement. Students of both systems acknowledged the importance of higher education in achieving elevated career and social growth, but, surprisingly, a majority of students from both education systems emphasized that clearing the examination was more important than enhancing their conceptual understanding of the subject matter (76\% under TES and $93 \%$ under OES). The majority of OES students (71\%) cited various excuses (lack of time, inaccessibility of tutor and peers to solve doubts, problems with course material, etc.) for not being able to study regularly. Similarly, $91 \%$ of OES students were dedicated to fulfilling their job and family responsibilities, making learning secondary. 


\section{Results and Discussion}

Overall, the present study concludes that there is significant difference in the levels of academic motivation between TES and OES students. The results further show that TES students are more motivated than OES students. On all dimensions, TES students have scored higher means compared to OES students. Students of OES are found to be low on personal aspiration and study habits and less motivated, and they do not have much of a positive attitude towards their study centers. Differences in the means of the two types of students is greater in the study habits and personal aspiration dimensions. This suggests that regular classroom studies, regular teacher-student interaction, regular discussions among students, availability of library facilities, and so on help develop better study habits in TES students. Further, it can be concluded that due to the different social environment settings of the students, there are differences in motivation levels. TES students generally are more conscious about their family and society. Analysis of different statements suggests that parents and society play a major role in the academic decision-making process of these students. They feel it is important and prestigious to attain a good position in their studies.

On the other hand, OES students are self-reliant and are generally engaged in some other occupation. Their first priorities may be job, family, or other things rather than devoting regular time towards studies. Their personal aspiration extends merely to passing the examination and obtaining the degree. This results in poor study habits. It is the intrinsic motivation which drives the students' will to learn in OES. It is also seen from the descriptive analysis of the questionnaire that a majority of students (in both TES and OES) have a superficial approach to learning habits.

Kawachi (2006, p.3) in his research on the learning of distance education pupils has identified four motivations that are helpful to the will to learn: vocational, academic, personal, and social. The intrinsic and extrinsic motivation factors to learn are summarized in Figure 6. 


\section{MOTIVATION}

Vocational Extrinsic : seeking qualification for a better job

Intrinsic : acquiring skills for own future desires

Academic Extrinsic : want to pass exams, get good grades

Intrinsic : pursuing own intellectual interests

Personal Extrinsic : prove one's capability to others

Intrinsic : desire for self improvement

Social Extrinsic : extracurricular sports, club activities

Intrinsic : integrative, affiliative online

and lifelong learning

Figure 6. The motivation to learn (Kawachi, 2006).

The AMS statements used in this research have integrated the factors explained by Kawachi (2006). Analysis of the questionnaire shows that OES learners have lower average scores on these factors compared to TES learners. It can be concluded that extrinsic motivation is not prominent in OES students. On the other hand, extrinsic motivation is an important factor along with intrinsic motivation in TES students. Beck (2005, p. 257, 264) has stated that anxiety and frustration are strongly motivating. This study concludes that there are lower amounts of anxiety and frustration in OES students with respect to their learning habits. The reasons for lower frustration and lower anxiety are mainly related to the immediate results that TES and OES produce. TES students see immediately the results of their studies as their degrees make them eligible for various competitive exams and job opportunities. Thus immediate rewards are associated with effort by the students of TES. On the other hand, for a large section of OES students, no such immediate reward is perceived as most of them are preengaged with other commitments.

The following conclusions can be generalized.

- TES students show better study habits as there are immediate rewards and punishment.

- TES students have more regular study habits mainly due to their regular classroom teaching and peer interactions than OES students.

- The academic environment in TES colleges has a positive motivation on these students compared to OES students. 
- Extrinsic motivation has a greater and immediate effect on the motivation level of TES students. Intrinsic motivation is a governing factor in the accomplishments in OES. Since extrinsic motivation is not as valuable for the students of OES, their overall motivation level is low.

- Gender-wise analysis shows that the motivation levels of male and female students of one system compared to the levels of male and female students of the other system differ significantly.

\section{Conclusions}

We see that OES students are low in extrinsic motivation, which results in an overall lower motivation level. The difference in the levels of motivation between students of TES and OES is significant. To increase the extrinsic motivation level, recognition and worth of the degrees obtained from OES should be increased. The importance of extrinsic motivation has also been acknowledged by Hartnett et al. (2011) in their recent research: "While intrinsic motivation constituted an important part of students' motivation to learn in the contexts described here, identified regulation (i.e., recognising the value and importance of the activity) was also important."

Policy makers are gradually increasing the worth of degrees procured under OES by making these degrees eligible for students to appear for job interviews and write various competitive examinations. This trend is also evident from the fact that, these days, various advertisements published by institutions/universities offering courses through distance learning are highlighting the equivalence of these degrees to the degrees of TES as far as eligibility for competitive examinations. This can be said to be a step in the right direction but it is also true that such degree holders must be capable to stand at par in knowledge and skills with the students of the traditional education system, which is why the evaluation process of OES becomes important to assure quality.

Facilities at the study centers should be improved and involvement of students in the academic process should be increased under OES to develop positive attitudes towards their education system. The role and intervention of tutors along with peer interaction are of paramount importance (Kawachi, 2006) in developing motivation among students to learn.

The basic natures of the two systems are different and so require altogether different approaches to run and manage the education process. The traditional education system depends more on verbal communication and methodologies to impart education thus making it quick and having an immediate effect (in the form of immediate rewards and feedback). On the other hand, the education process of OES is largely completed through written or other media communication involving distances and depends upon many intermediaries. Consequently, the types of skills required in faculty members, students, and administrative personnel are significantly different in the two types of education systems. Administrators and faculty members of OES should be able to design study materials in a way that is effective and easy to comprehend by the students. The importance of administrative roles 
increases in OES so that course materials and feedback/evaluation are available to students on time and records are updated continuously and correctly. The role of administrators and tutors can also be stretched to keep track of failing students and to guide them towards successful completion of the course by sending motivating letters.

Research can be undertaken to investigate if there is a positive relationship between the personality traits of students pursuing education through OES and successful course completion. Such traits, if any, can be identified and used to formulate policies and strategies for effective governance of OES. Registration and entrance tests may contain a few questions or statements designed to help judge the personality traits of prospective candidates seeking admission to OES courses. This may help in formulating strategies and policies to reduce the dropout rates. The time required to complete a syllabus should be known to OES students beforehand to make them aware of the time and energy they need to put in for successful completion of the course.

In summary, enhancing infrastructure facilities, increasing the worth of degrees, increasing the roles of tutors, and increasing familiarity with technology and administrative correctness and innovation are paramount in OES to lessen the motivation differences between the students of the two systems. 


\section{References}

Aggarwal, J.C. (2004). Essentials of educational psychology. New Delhi: Vikas Publishing House Pvt. Ltd.

Anderson, T. (2006). Higher education evolution: Individual freedom afforded by educational social software. In M. Beaudoin (Ed.), Perspectives on the future of higher education in the digital age (pp. 77-90). New York: Nova Science Publishers.

Atman, K. (1988). Psychological type elements and goal accomplishment style: Implications for distance education. The American Distance Journal of Education, 2(3). Retrieved from http://www.ajde.com/Contents/vol2_3.htm

Banerjee, T. (1974). Academic motivation-development of a questionnaire. The Bureau of Educational and Psychological Research, Govt. of West Bengal, Calcutta. In M.B. Buch (1986) (Ed.), Third survey of research in education. NewDelhi: NCERT.

Bhattacharya, S. (1991). Open University-Its scope and possibilities: An analysis of Tagore's educational thoughts in evolving a conceptual framework of open university in India. In M.B. Buch (2000) (Ed.), Fifth survey of research in education (Vol.1, pp. 1572-1573). New Delhi: NCERT.

Beck, R.C. (2005). Motivation: Theories and principles. ( $4^{\text {th }}$ ed.). Pearson Education, Delhi.

Bolocofsky, D.N. (1980). Motivational effect of classroom competition as a function of field dependence. The Journal of Educational Research, 73(4), 213.

Daft, R. L. (1977). Management (4 ${ }^{\text {th }}$ ed.). Orlando, Fl.: Harcourt Brace.

Entwistle, N.J. (1968). Academic motivation and school attainment. British Journal of Educational Psychology, 38(2), 181-188.

Fozdar, B.I., Kumar, L.S., \& Kannan, S. (2006). A survey of a study on the reasons responsible for student dropout from the bachelor of science programme at Indira Gandhi National Open University. International Review of Research in Open and Distance Learning, 7(3). Retrieved from http://www.irrodl.org/index.php/irrodl/ article/view/291/755

Frymier, J.R., Norris, L., Henning, M. J., Henning, W. Jr., \& West, S. C. (1975). A longitudinal study of academic motivation. The Journal of Educational Research, 69(2).

Garrett, H.E. (1981). Statistics in psychology and education. Kalyani Publishers Ludhiana $\mathrm{Pb}$.

Gautam, R. (1990). A study of success in distance learning system in relation to some key learned and institutional variables. In M.B. Buch (2000) (Ed), Fifth survey of research in education (pp. 1573-1574). New Delhi: NCERT. 
Gibson, C. C. (1996). Toward an understanding of academic self-concept in distance education. American Journal of Distance Education, 1O(1). Retrieved from http://www. ajde.com/Contents/vol1o_1.htm

Hartnett, M., George, St. A., \& Dron. J. (2011). Examining motivation in online distance learning environments: Complex, multifaceted, and situation-dependent. International Review of Research in Open and Distance Learning, 12(6). Retrieved from http://www.irrodl.org/index.php/irrodl/article/view/1030/1954.

Hussain, M.Q. (1977). A study of academic attainment in relation to level of aspiration and anxiety. In M.B. Buch (1986) (Ed.). Third survey of research in education ( $p p$. 667-668). NewDelhi: NCERT.

Indradevi, V. (1985). Philosophical analysis of the concept of distance education and its implication on the emerging non-formal systems of education with special reference to teacher education. In M.B. Buch (1991), (Ed.), Fourth survey of research in Education (Vol. 1, pp. 944-945). New Delhi: NCERT.

Karsenti, T. (1999). Student motivation and distance education on the Web: Love at first sight? Retrieved from http://www.unb.ca/naweb/proceedings/1999/karsenti/ karsenti.html

Kawachi, P. (2006). The will to learn: Tutor's role. In P.R. Ramanujam (Ed.) Globalisation, education and open distance learning (pp. 197-221). New Delhi, India: Shipra. Retrieved from http://www.open-ed.net/library/R3107.pdf

Khan, N. (1991). Effectivity of distance education programme with reference to the teachers' training course. In M.B. Buch, (2000) (Ed.), Fifth survey of research in education (Vol.1, p. 532). New Delhi: NCERT.

McClelland et al. (1953). The achievement motive. Princton, N.J.:D. Van Nostrand.

McIntosh, N.E. (1978). What do we know about our students? Recent research on women in adult education: The Open University experience. International Council for Correspondence Education: Dynamic and Diversified, Vol.2, New Delhi.

Miller, D. C. (1977). Handbook of research design and social measurement. New York: David Mc Kay Company, Inc.

Muilenburg, L. Y., \& Berge, Z. L. (2005). Student barriers to online learning: A factor analytic study. Distance Education, 26(1), 29-48. doi: 10.1080/01587910500081269

Nagalakshmi, B. (1982). A study of perceived behaviour and the level of academic motivation of class IX students. In M.B. Buch (1986) (Ed.), Third survey of research in education (p. 382). NewDelhi: NCERT. 
Paulsen, M. F. (1993). The hexagon of cooperative freedom: A distance education theory attuned to computer conferencing. DEOSNEWS, 3(2).

Pierrakeas, C., \& Xenos, M. (2004). A comparative study of dropout rates and causes for two different distance education courses. International Review of Research in Open and Distance Learning, 5(2). Retrieved from http://www.irrodl.org/index. $\mathrm{php} / \mathrm{irrodl} /$ article/view/183/804

Rovai, A. P., Ponton, M., Wighting, M., \& Baker, J. (2007). A comparative analysis of student motivation in traditional classroom and e-learning courses. International Journal on E-Learning, 6(3), 413-432.

Salunke, R.B. (1979). A study of the home environment, socio-economic status and economic management in relation to the academic achievement of the first year college students. In M.B. Buch (1986) (Ed.), Third survey of research in education (pp. 685-686). NewDelhi: NCERT.

Satyanandam, B.D. (1969). A study of socio-economic status and academic achievement. In M. B. Buch (1986) (Ed.), Third survey of research in education (p. 686). NewDelhi: NCERT.

Schifter, C. \& Monolescu, D. (2000). Evaluating students online course experiences. The virtual focus group. Retrieved from http://www.ed.psu.edu/acsde/deos/deosnews/deosnews10_9.asp

Siddiqui, B.B. (1979). Effects of achievement motivation and personality on academic success. In M.B. Buch (1986) (Ed.). Third survey of research in education (pp. 690691). NewDelhi: NCERT.

Singh, S. (1984). Relationship of home environment need for achievement and academic motivation with academic achievement. In M.B. Buch (1991) (Ed.), Fourth survey of research in education (Vol.1, pp. 856-857). New Delhi: NCERT.

Shroff, R. H., Vogel, D. R., \& Coombes, J. (2008). Assessing individual-level factors supporting student intrinsic motivation in online discussions: A qualitative study. Journal of Information Systems Education, 19(1), 111-125.

Tiwari, G.N. (1982). Study habits and scholastic performance at three levels of education. In M.B. Buch (1991) (Ed.). Fourth survey of research in education (Vol.1, pp. 862863). New Delhi: NCERT.

Tseng, V. (1998). Academic motivation, achievement and decision among students from immigrant and U.S born families. Retrieved from http://tigger.uic.edu/ thork/ Trust/Tseng.htm

Waniewicz, G. (1986). The adult learners: Who are they, why and where do they learn? 
ICDE Conference Paper.

Wighting, M. J., Liu, J., \& Rovai, A. P. (2008). Distinguishing sense of community and motivation characteristics between online and traditional college students. Quarterly Review of Distance Education, 9(3), 285-295.

Yeung, N. T. Y., \& Yeung, A, S. (2001). Does school motivation change over secondary school years? Paper presented at AARE, the University of Notre Dame, Fremantle, Western Australia. Retrieved from http://www.aare.edu.au/o1pap/yeu01019.htm

\section{Athabasca University $\mathbf{A}$}

(c) (†) 